\title{
Professional who attended childbirth and breastfeeding in the first hour of life
}

\author{
Profissional que assistiu o parto e amamentação na primeira hora de vida \\ Profesional que asistió al parto y amamantamiento en la primera hora de vida
}

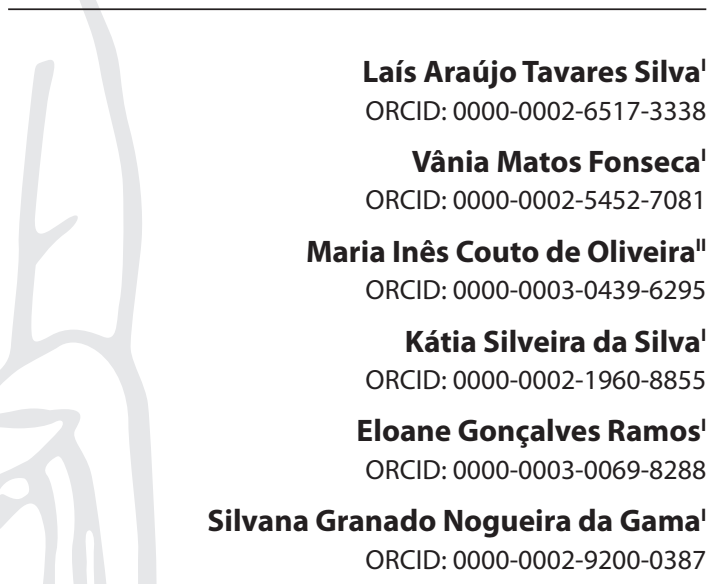

' Fundação Oswaldo Cruz. Rio de Janeiro, Rio de Janeiro, Brazil. "Universidade Federal Fluminense. Niterói, Rio de Janeiro, Brazil.

How to cite this article: Silva LAT, Fonseca VM, Oliveira MIC, Silva KS, Ramos EG, Gama SGN. Professional who attended childbirth and breastfeeding in the first hour of life. Rev Bras Enferm. 2020;73(2):e20180448. doi: http://dx.doi.org/10.1590/0034-7167-2018-0448

Corresponding Author:

Laís Araújo Tavares Silva

E-mail: laisaraujots@gmail.com

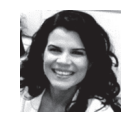

EDITOR IN CHIEF: Antonio José de Almeida Filho ASSOCIATE EDITOR: Margarida Vieira

Submission: 06-15-2018 Approval: 09-29-2018

\begin{abstract}
Objectives: To investigate the association between the professionals who attended vaginal delivery and breastfeeding in the first hour of life. Methods: This is a crosssectional study with data from the Nascer no Brasil (Born in Brazil) survey, conducted in the 2011-2012 period. Data from 8,466 puerperae were analyzed using a logistic regression model with a hierarchical approach. Results: The proportion of mothers who breastfed at birth was higher in deliveries attended by nurses (70\%). A nurse-assisted delivery was $64 \%$ more likely to breastfeed in the first hour of life. Other factors associated with the outcome: residing in the North; age less than 35 years; multiparity; prenatal guidance on breastfeeding in the first hour of life; birth at Baby-Friendly Hospital; companion at birth; and female newborn. Conclusions: Obstetrician nurse/nurse-assisted delivery was a significant independent factor associated with breastfeeding in the first hour of life, suggesting the importance of strengthening the role of the obstetrician nurse.

Descriptors: Nurse Midwives; Midwifery; Postpartum Period; Breast Feeding; CrossSectional Studies.
\end{abstract}

\section{RESUMO}

Objetivos: investigar a associação entre o profissional que assistiu o parto vaginal e a amamentação na primeira hora de vida. Métodos: estudo transversal com dados da pesquisa Nascer no Brasil, conduzida em 2011/2012. Foram analisados dados de 8.466 puérperas por meio de modelo de regressão logística com abordagem hierarquizada. Resultados: A proporção de mães que amamentaram ao nascimento foi maior nos partos assistidos pelo enfermeiro (70\%). O parto assistido por enfermeiro apresentou chance $64 \%$ maior de amamentação na primeira hora de vida. Outros fatores associados ao desfecho: residir no Norte; idade inferior a 35 anos; multiparidade; orientação no pré-natal sobre amamentação na primeira hora de vida; nascimento em Hospital Amigo da Criança; acompanhante no parto; e recém-nascido de sexo feminino. Conclusões: $O$ parto assistido pelo enfermeiro/enfermeiro obstetra foi importante fator independente associado à amamentação na primeira hora de vida, sugerindo a importância do fortalecimento do papel do enfermeiro obstetra.

Descritores: Enfermeiras Obstétricas; Tocologia; Período Pós-Parto; Aleitamento Materno; Estudos Transversais.

\section{RESUMEN}

Objetivos: investigar la asociación entre el profesional que asistió al parto vaginal y la lactancia en la primera hora de vida. Métodos: estudio transversal con datos de la investigación Nascer no Brasil (Nacer en Brasil), conducida en el periodo de 2011-2012. Se analizaron datos de 8.466 puérperas por medio de modelo de regresión logística con abordaje jerarquizado. Resultados: La proporción de madres que amamantaron al nacimiento fue mayor en los partos asistidos por el enfermero (70\%). El parto asistido por enfermero presentó una probabilidad un $64 \%$ mayor de lactancia en la primera hora de vida. Otros factores asociados al desenlace: residir en el Norte; edad inferior a 35 años; multiparidad; orientación en el prenatal sobre lactancia materna en la primera hora de vida; nacimiento en el Hospital Amigo del Niño; acompañante en el parto; y el recién nacido de sexo femenino. Conclusiones: El parto asistido por el enfermero/enfermero obstetra fue un importante factor independiente asociado a la lactancia materna en la primera hora de vida, sugiriendo la importancia del fortalecimiento del papel del enfermero obstetra. Descriptores: Enfermeras Obstetrices; Partería; Periodo Posparto; Lactancia Materna; Estudios Transversales. 


\section{INTRODUCTION}

The leading global initiative for the promotion of breastfeeding in maternal and child services is the Baby-Friendly Hospital Initiative (IHAC). Of the "Ten Steps to Successful Breastfeeding" advocated by the IHAC, Step 4, referring to breastfeeding in the first hour of life $\mathrm{e}^{(1)}$, is highlighted in order to contribute to the reduction of neonatal mortality ${ }^{(2-3)}$. Studies indicate that differences in maternity care models may interfere with the early initiation of breastfeeding when mothers' decision-making power tends to be more limited, making them dependent on the institutional and professional protocols involved in childbirth ${ }^{(4-5)}$.

In 2014, Brazil included in the criteria for qualification to the IHAC the "Women-Friendly Care" (CAM) ${ }^{(6)}$, aiming to promote "Good Delivery and Childbirth Care Practices"(7), since the indiscriminate use of interventions has been a feature of the Brazilian obstetric care model $^{(8)}$. One of the strategies of the Ministry of Health, based on the humanization of delivery and childbirth, and due to the need to change the current technocratic care model, was the implantation of low-risk normal delivery by the obstetrician nurse, following successful international examples ${ }^{(9)}$. Obstetrical Nursing Specialization Courses and Residency Programs have been funded since the early 2000 s with the aim of training nurses incorporated into the Unified Health System (SUS) ${ }^{(10)}$, along the lines of the Rede Cegonha (Stork Network)(11).

According to The Lancet, obstetrical care provides better results in reducing maternal and neonatal mortality when performed by trained midwives, and in collaborative work with a multidisciplinary team ${ }^{(12-13)}$. The Brazilian Association of Obstetrician Nurses (ABNFO) adopted the "Essential Competencies for Basic Midwifery" of the International Confederation of Midwives (ICM), the Pan-American Health Organization (PAHO) developed the "Toolkit for Strengthening Professional Midwifery in the Americas", adapted to the Brazilian context ${ }^{(14)}$, and in 2017, the Ministry of Health published the "National Guidelines for Normal Childbirth Care"(15-16).

This study is part of international recognition of the role of the professional midwife as a strategy to improve delivery and childbirth care. The practices adopted by the obstetrician nurse regarding breastfeeding in the first hour of life can be an essential marker of the delivery model.

\section{OBJECTIVES}

To investigate the association between the professional who attended vaginal delivery and breastfeeding in the first hour of life.

\section{METHODS}

\section{Ethical aspects}

This study considered the ethical precepts of Resolution 466/2012 of the National Health Council. The Research Nascer no Brasil (Born in Brazil) was approved by the Research Ethics Committee of the National School of Public Health/Oswaldo Cruz Foundation and the consent obtained in digital format, and puerperae received the printed version of the informed consent form.

\section{Design, place of study and period}

This is a cross-sectional hospital-based study with a national scope, based on data from the study Nascer no Brasil: Pesquisa Nacional sobre Parto e Nascimento (Born in Brazil: National Survey on Delivery and Childbirth), conducted from February 2011 to October 2012.

\section{Sample and inclusion/exclusion criteria}

A probabilistic complex sample was used to represent all births occurring in hospitals with 500 or more births per year, stratified by the five geographic macro-regions, by location (capital or non-capital) and hospital type (private, public or mixed). Then, the necessary days were selected to reach 90 puerperae (a minimum of seven days in each hospital). In the third stage, the sample consisted of the puerperae. A total of 266 hospitals were sampled from 191 Brazilian municipalities, and 23,894 puerperae were interviewed. The detailed description of the sample design is found in Vasconcellos et al. ${ }^{(17)}$.

For the present study, single-gestation vaginal deliveries with term birth (37-41 gestation weeks) were performed by doctors or nurses/obstetrician nurses. Fetal or neonatal deaths, maternal deaths, maternal near miss at delivery, HIV-positive women, newborns with an Apgar score below seven in the $5^{\text {th }}$ minute of life, newborns who required resuscitation in the delivery room and whose destination was the ICU - characteristics that could prevent or delay the initiation of breastfeeding were excluded. After applying these criteria, the final sample included 8,466 puerperae for analysis.

\section{Study protocol and variables}

The research team consisted of executive, regional and state coordinators, 50 supervisors and 200 interviewers, who received local training for five consecutive days. Interviews were held with the puerperae during hospitalization at the health service, using a standardized electronic questionnaire, and their prenatal cards were photographed. Data were also extracted from the medical records of the puerperae and the newborns. The supervisor of each unit sent data to a central search server for real-time storage and monitoring. The hospital interview data collection instrument contained 397 questions, including blocks of repeated questions for up to quadruplets. The instrument used to collect data from the medical record contained 265 items.

In this study, the exposure variable investigated was the professional who attended the delivery (doctor or nurse/obstetrician nurse), obtained by consulting the medical records. The outcome variable was breastfeeding in the first hour of life (yes/no), categorized based on questions related to the time of onset of breastfeeding and breastfeeding in the delivery room.

It may be that outside urban centers some nurses without specialization in obstetrics attend vaginal deliveries. Therefore, in this study, professionals with an undergraduate degree and nurses with a specialization in obstetrics were considered. In the Nascer no Brasil study, there were no obstetricians graduated in obstetrics working in maternity hospitals, since their professional registration has been recently regulated in Brazil ${ }^{(18)}$. 


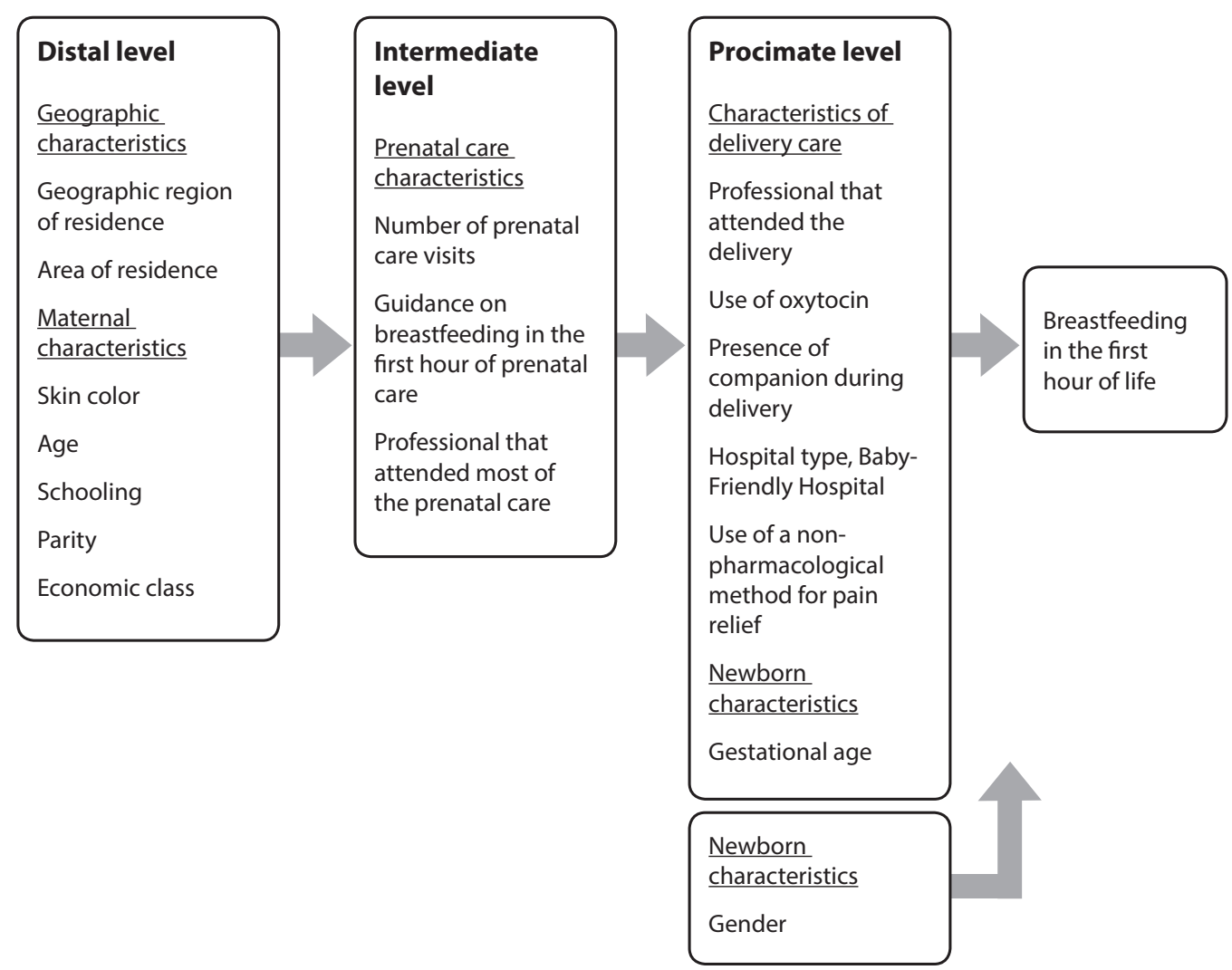

Figure 1 - Conceptual model of breastfeeding in the first hour of life at hierarchical levels of determination

analysis of the outcome with each variable was performed using Pearson's chi-square test, and crude odds ratios (OR) were estimated. The variables whose association with the outcome showed $p$-value $\leq 0.20$ were selected for the construction of a logistic regression model, following a three-level hierarchical approach. At each level, variables were included following the forward selection method, with a criterion of $p<0.05$ to remain in the model. The adjusted ORs with the respective $95 \%$ confidence intervals $(95 \% \mathrm{Cl})$ were estimated, and the variables with $p$-value $\leq 0.05$ were considered statistically significant with the outcome. Interactions between the variables

A hierarchical conceptual model was constructed at the distal, intermediate and proximal levels (Figure 1) based on a systematic review of the factors associated with breastfeeding in the first hour $^{(19)}$ in order to perform a multivariate analysis approach. The variables used were obtained from the maternal hospital interview and the maternal medical record, defined as follows: Geographic region of residence (North, Northeast, Southeast, South or Midwest); area of residence (capital/inland); self-reported maternal skin color (white/non-white); maternal age (12-19 years/20-34 years/ $\geq 35$ years); maternal schooling ( $<11$ years of schooling / $\geq 11$ years of schooling); parity (primiparous / multiparous); economic class ( $A / B, C$ or D/E, based on the criteria of the Brazilian Association of Research Companies - ABEP/2010); number of prenatal visits (did not do prenatal care/1-5/6 or more); guidance on breastfeeding in the first hour of prenatal care (yes/no); health professional who attended most of the prenatal visits (doctor/ nurse); care attendant (physician/nurse or obstetrician nurse); use of oxytocin in labor (yes/no); presence of companion at delivery (yes/no); hospital type (public/mixed/private); Baby-Friendly Hospital (no/underway/yes); use of some non-pharmacological method for pain relief (yes/no); gestational age at birth (preterm: 37 to $<39$ weeks / term: 39 to $<41$ weeks / late term: 41 to $<42$ weeks) and baby gender (female/male).

\section{Analysis of results and statistics}

The software used in the statistical analysis was the data analysis package with SPSS 22.0 complex samples. Initially, bivariate
"Baby-Friendly Hospital", "presence of companion at delivery" and "hospital type" were tested.

\section{RESULTS}

Of the 8,466 puerperae who delivered vaginally, $60.9 \%$ breastfed their infants in the first hour after birth. Most of the puerperae were non-white, in the 20-34 years' age group, had less than 11 years of study, were multiparous and of economic class $C$ (Table 1). Regarding the prenatal care characteristics, most attended six prenatal visits or more, reported having received guidance on breastfeeding in the first hour of life and was attended by the doctor in most visits (Table 2). Regarding delivery, most puerperae were attended by doctors ( $83 \%)$. The proportion of mothers who breastfed in the first hour of life was higher in deliveries attended by a nurse/obstetrician nurse (70\%) than in those attended by the doctor (59\%). There was a preponderance of births without the presence of companions (66\%) and in public or mixed hospitals (97\%). Non-pharmacological methods for pain relief were used in one-third of the sample (Table 3).

After the bivariate analysis, the following maternal sociodemographic variables showed $p$-value $\leq 0.20$ in the test of association with the outcome: geographical region, age, schooling and parity (Table 1); among the variables related to prenatal care: guidance on breastfeeding in the first hour of life (Table 2); and among the variables related to childbirth care and characteristics of the newborn: professional attending delivery, presence of companion at delivery, hospital type, Baby-Friendly Hospital, use of 
some non-pharmacological method for pain relief during labor, gestational age and gender of the newborn (Table 3 ).

Table 4 shows the models as per the level of proximity to the outcome, considering the level of significance of $5 \%$. The likelihood of breastfeeding at birth was higher in newborns whose mothers were residents in the North; adolescents or adults between 20 and 34 years of age; multiparous; who received guidance on breastfeeding in the first hour of life in prenatal care; had their children in Baby-Friendly Hospital; nurse/obstetrician nurse attended delivery; presence of companion at delivery; and female newborns. The characteristics with a higher association with the outcome were maternal age from 12 to 19 years, with a $61 \%$ likelihood ( $p=0.001)$, birth at a Baby-Friendly Hospital, with a $66 \%$ likelihood ( $p=0.004)$, and delivery attended by a nurse/obstetrician nurse, associated with a $64 \%$ likelihood of breastfeeding in the first hour of life $(p=0.004)$ (Table 4).

Table 1 - Breastfeeding in the first hour of life, per maternal geographic and sociodemographic characteristics - Distal level, Brazil, 2011-2012

\begin{tabular}{|c|c|c|c|c|}
\hline Variables & n (\%) & Breastfeeding in the first hour of life (\%) & $\begin{array}{c}\text { Crude OR } \\
(95 \% \mathrm{CI})\end{array}$ & $p$ value \\
\hline \multicolumn{5}{|c|}{ Geographic region $(n=8,466)$} \\
\hline North & $759(9.0)$ & 71.8 & $1.78(1.16-2.75)$ & 0.008 \\
\hline Midwest & $509(6.0)$ & 66.2 & $1.37(0.88-2.15)$ & 0.159 \\
\hline South & $1.013(12.0)$ & 65.3 & $1.32(0.84-2.09)$ & 0.224 \\
\hline Northeast & $2.405(28.4)$ & 58.0 & $0.97(0.68-1.37)$ & 0.864 \\
\hline Southeast & $3.780(44.7)$ & 58.7 & 1 & \\
\hline \multicolumn{5}{|c|}{ Area of residence $(n=8,466)$} \\
\hline Capital & $3.372(39.8)$ & 61.5 & 1 & \\
\hline Inland & $5.093(60.2)$ & 60.5 & $0.95(0.70-1.29)$ & 0.781 \\
\hline \multicolumn{5}{|l|}{ Skin color $(n=8,464)$} \\
\hline White & $2.401(28.4)$ & 60.8 & 1 & \\
\hline Non-white & $6.062(71.6)$ & 61.0 & $1.00(0.84-1.20)$ & 0.931 \\
\hline \multicolumn{5}{|l|}{ Maternal age $(n=8,466)$} \\
\hline $12-19$ years & $2.032(24.0)$ & 62.3 & $1.45(1.12-1.88)$ & 0.004 \\
\hline $20-34$ years & $5.805(68.6)$ & 61.3 & $1.40(1.11-1.75)$ & 0.004 \\
\hline$\geq 35$ years & $629(7.4)$ & 53.1 & 1 & \\
\hline \multicolumn{5}{|l|}{ Schooling $(n=8,466)$} \\
\hline$\geq 11$ years of study & $3.117(36.8)$ & 59.3 & 1 & \\
\hline$<11$ years of study & $5.349(63.2)$ & 61.8 & $1.11(0.96-1.28)$ & 0.157 \\
\hline \multicolumn{5}{|l|}{ Parity $(\mathrm{n}=8,466)$} \\
\hline Primiparous & $3.544(41.9)$ & 58.9 & 1 & \\
\hline Multiparous & $4.922(58.1)$ & 62.4 & $1.15(1.00-1.33)$ & 0.044 \\
\hline \multicolumn{5}{|l|}{ Economic class $(n=8,404)$} \\
\hline$A ; B$ & $1.261(15.0)$ & 59.9 & 1 & \\
\hline C & $4.598(54.7)$ & 59.4 & 0.97(0.79-1.20) & 0.840 \\
\hline$D ; E$ & $2.544(30.3)$ & 63.8 & $1.17(0.91-1.52)$ & 0.212 \\
\hline
\end{tabular}

Table 2 - Breastfeeding in the first hour of life, by prenatal care characteristics - Intermediate Level. Brazil, 2011-2012

\begin{tabular}{|c|c|c|c|c|}
\hline Variables & n (\%) & $\begin{array}{l}\text { Breastfeeding in the } \\
\text { first hour of life (\%) }\end{array}$ & $\begin{array}{c}\text { Crude OR } \\
(95 \% \mathrm{Cl})\end{array}$ & $p$ value \\
\hline \multicolumn{5}{|l|}{ Number of PN visits* $(n=8,290)$} \\
\hline Did not perform PN & $125(1.5)$ & 56.5 & 1 & \\
\hline $1-5$ visits & $2.545(30.7)$ & 63.6 & $1.34(0.77-2.34)$ & 0.293 \\
\hline 6 or more visits & $5.620(67.8)$ & 59.8 & $1.14(0.65-1.99)$ & 0.634 \\
\hline \multicolumn{5}{|c|}{ Guidance on breastfeeding in the first hour of life in PN $(n=8,421)$} \\
\hline No or did not perform PN & $3.278(38.9)$ & 57.8 & 1 & \\
\hline Yes & $5.143(61.1)$ & 62.8 & $1.23(1.02-1.48)$ & 0.031 \\
\hline \multicolumn{5}{|c|}{ Health professional who attended most PN visits $(n=8,193)$} \\
\hline Doctor & $5.820(71)$ & 60.8 & 1 & \\
\hline Nurse & $2.373(29)$ & 61.3 & $1.02(0.83-1.25)$ & 0.841 \\
\hline
\end{tabular}

*PN-Prenatal care.

Table 3 - Breastfeeding in the first hour of life, per delivery care and baby characteristics - Proximal level, Brazil, 2011-2012

\begin{tabular}{|c|c|c|c|c|}
\hline Variables & n (\%) & $\begin{array}{l}\text { Breastfeeding in the } \\
\text { first hour of life (\%) }\end{array}$ & $\begin{array}{l}\text { Crude OR } \\
(95 \% \mathrm{CI})\end{array}$ & $p$ value \\
\hline \multicolumn{5}{|c|}{ Professional that attended delivery $(n=8,466)$} \\
\hline Doctor & $7.062(83.4)$ & 59.0 & 1 & \\
\hline Nurse/obstetric nurse & $1.404(16.6)$ & 70.5 & $1.66(1.17-2.36)$ & 0.005 \\
\hline \multicolumn{5}{|c|}{ Use of oxytocin during labor $(n=8,466)$} \\
\hline Yes & $4.087(48.3)$ & 60.0 & 1 & \\
\hline No & $4.379(51.7)$ & 61.8 & $1.08(0.91-1.28)$ & 0.365 \\
\hline
\end{tabular}




\begin{tabular}{|c|c|c|c|c|}
\hline Variables & n (\%) & $\begin{array}{l}\text { Breastfeeding in the } \\
\text { first hour of life (\%) }\end{array}$ & $\begin{array}{l}\text { Crude OR } \\
(95 \% \mathrm{Cl})\end{array}$ & $p$ value \\
\hline \multicolumn{5}{|c|}{ Companion during delivery $(\mathrm{n}=8,465)$} \\
\hline No & $5.572(65.8)$ & 58.0 & 1 & \\
\hline Yes & $2.893(34.2)$ & 66.6 & 1.44(1.17-1.77) & 0.001 \\
\hline \multicolumn{5}{|l|}{ Hospital type $(n=8,466)$} \\
\hline Private & 268 (3.2) & 42.2 & 1 & \\
\hline Mixed & $3.815(45.1)$ & 58.6 & $1.93(1.06-3.53)$ & 0.031 \\
\hline Public & $4.383(51.8)$ & 64.1 & $2.44(1.36-4.38)$ & 0.003 \\
\hline \multicolumn{5}{|c|}{ Baby-Friendly Hospital $(8,466)$} \\
\hline No & $4.217(49.8)$ & 54.3 & 1 & \\
\hline Underway & $789(9.3)$ & 61.6 & $1.34(0.81-2.22)$ & 0.239 \\
\hline Yes & $3.460(40.9)$ & 68.8 & $1.85(1.37-2.49)$ & $<0.001$ \\
\hline \multicolumn{5}{|c|}{ Use of non-pharmacological method for pain relief $(n=8,466)$} \\
\hline No & $5.621(66.4)$ & 59.4 & 1 & \\
\hline Yes & $2.845(33.6)$ & 63.9 & $1.20(0.99-1.45)$ & 0.051 \\
\hline \multicolumn{5}{|c|}{ Gestational age $(n=8,465)$} \\
\hline 37 to $<39$ weeks & $3.052(36.1)$ & 59.4 & $0.79(0.64-0.99)$ & 0.048 \\
\hline 39 to $<41$ weeks & $4.645(54.9)$ & 61.3 & $0.86(0.70-1.07)$ & 0.185 \\
\hline 41 to $<42$ weeks & $768(9.1)$ & 64.6 & 1 & \\
\hline \multicolumn{5}{|c|}{ Newborn gender $(n=8,464)$} \\
\hline Male & $4.338(51.3)$ & 59.4 & 1 & \\
\hline Female & $4.126(48.7)$ & 62.5 & $1.13(1.00-1.28)$ & 0.037 \\
\hline
\end{tabular}

Table 4 - Models of factors associated with breastfeeding in the first hour of life, Brazil, 2011-2012

\begin{tabular}{|c|c|c|c|c|c|c|}
\hline \multirow{2}{*}{ Variables } & \multicolumn{2}{|c|}{$\begin{array}{c}\text { Distal model } \\
n=8,466\end{array}$} & \multicolumn{2}{|c|}{$\begin{array}{c}\text { Intermediate model* } \\
\qquad n=8,421\end{array}$} & \multicolumn{2}{|c|}{$\begin{array}{c}\text { Proximal model } \\
n=8,418\end{array}$} \\
\hline & $\begin{array}{l}\text { Adjusted OR } \\
(95 \% \mathrm{Cl})\end{array}$ & $p$ value & $\begin{array}{l}\text { Adjusted OR } \\
(95 \% \mathrm{Cl})\end{array}$ & $p$ value & $\begin{array}{c}\text { Adjusted OR } \\
(95 \% \mathrm{Cl})\end{array}$ & $p$ value \\
\hline \multicolumn{7}{|l|}{ LEVEL 1} \\
\hline $\begin{array}{l}\text { Geographic region } \\
\text { North } \\
\text { Midwest } \\
\text { South } \\
\text { Northeast } \\
\text { Southeast }\end{array}$ & $\begin{array}{c}1.73(1.12-2.67) \\
1.35(0.86-2.12) \\
1.33(0.84-2.10) \\
0.97(0.68-1.38) \\
1\end{array}$ & 0.032 & $\begin{array}{c}1.71(1.10-2.66) \\
1.31(0.83-2.05) \\
1.31(0.83-2.07) \\
0.93(0.66-1.32) \\
1\end{array}$ & 0.034 & $\begin{array}{c}1.74(1.12-2.71) \\
1.34(0.79-2.29) \\
1.26(0.80-1.97) \\
0.99(0.70-1.42) \\
1\end{array}$ & 0.050 \\
\hline $\begin{array}{l}\text { Maternal age } \\
12-19 \text { years } \\
20-34 \text { years } \\
\geq 35 \text { years }\end{array}$ & $\begin{array}{c}1.67(1.26-2.21) \\
1.45(1.16-1.81) \\
1\end{array}$ & 0.001 & $\begin{array}{c}1.68(1.26-2.23) \\
1.44(1.15-1.80) \\
1\end{array}$ & 0.001 & $\begin{array}{c}1.61(1.22-2.13) \\
1.42(1.13-1.77) \\
1\end{array}$ & 0.001 \\
\hline $\begin{array}{l}\text { Parity } \\
\text { Multiparous } \\
\text { Primiparous }\end{array}$ & $\begin{array}{c}1.25(1.05-1.48) \\
1\end{array}$ & 0.009 & $\begin{array}{c}1.26(1.07-1.50) \\
1\end{array}$ & 0.006 & $\begin{array}{c}1.26(1.05-1.50) \\
1\end{array}$ & 0.008 \\
\hline \multicolumn{7}{|l|}{ LEVEL 2} \\
\hline $\begin{array}{l}\text { Guidance on breastfeeding in the first } \\
\text { hour of life in prenatal care } \\
\text { Yes } \\
\text { Did not receive or do prenatal care }\end{array}$ & $\begin{array}{l}- \\
-\end{array}$ & $\begin{array}{l}- \\
-\end{array}$ & $\begin{array}{c}1.24(1.04-1.49) \\
1\end{array}$ & 0.016 & $\begin{array}{c}1.25(1.04-1.50) \\
1\end{array}$ & 0.016 \\
\hline \multicolumn{7}{|l|}{ LEVEL 3} \\
\hline $\begin{array}{l}\text { Baby-Friendly Hospital } \\
\text { Yes } \\
\text { Underway } \\
\text { No }\end{array}$ & $\begin{array}{l}- \\
- \\
-\end{array}$ & $\begin{array}{l}- \\
- \\
-\end{array}$ & $\begin{array}{l}- \\
- \\
-\end{array}$ & $\begin{array}{l}- \\
- \\
-\end{array}$ & $\begin{array}{c}1.66(1.23-2.25) \\
1.40(0.88-2.24) \\
1\end{array}$ & 0.004 \\
\hline $\begin{array}{l}\text { Professional that attended the delivery } \\
\text { Nurse/obstetric nurse } \\
\text { Doctor }\end{array}$ & $\begin{array}{l}- \\
- \\
-\end{array}$ & $\begin{array}{l}- \\
- \\
-\end{array}$ & $\begin{array}{l}- \\
- \\
-\end{array}$ & $\begin{array}{l}- \\
- \\
-\end{array}$ & $\begin{array}{c}1.64(1.17-2.29) \\
1\end{array}$ & 0.004 \\
\hline $\begin{array}{l}\text { Companion at delivery } \\
\text { Yes } \\
\text { No }\end{array}$ & $\begin{array}{l}- \\
- \\
-\end{array}$ & $\begin{array}{l}- \\
- \\
-\end{array}$ & $\begin{array}{l}- \\
- \\
-\end{array}$ & $\begin{array}{l}- \\
-\end{array}$ & $\begin{array}{c}1.33(1.09-1.64) \\
1\end{array}$ & 0.005 \\
\hline $\begin{array}{l}\text { Newborn gender } \\
\text { Female } \\
\text { Male }\end{array}$ & $\begin{array}{l}- \\
- \\
-\end{array}$ & $\begin{array}{l}- \\
- \\
-\end{array}$ & $\begin{array}{l}- \\
- \\
-\end{array}$ & $\begin{array}{l}- \\
- \\
-\end{array}$ & $\begin{array}{c}1.17(1.03-1.32) \\
1\end{array}$ & 0.010 \\
\hline
\end{tabular}

Note: * Intermediate model: adjusted for the statistically significant variables of the Distal Model $(p<0.05) ; * *$ Proximal model: adjusted for the statistically significant variables of the distal and intermediate models $(p<0.05)$. 


\section{DISCUSSION}

In Brazil, in the 2011-2012 period, breastfeeding in the first hour of life was performed in $60.9 \%$ of vaginal deliveries, higher than that estimated by the 2006 National Survey of Demography and Health (PNDS), with a percentage of $51.1 \%$ of children breastfed in the first hour of life in vaginal deliveries ${ }^{(8)}$. These variations may result from different sampling strategies and a possible memory bias related to the methodology used. In the PNDS, data was collected with mothers whose children were up to five years of age, whereas in this study, information was collected directly from the mothers during the maternity stay. Also, until the data collection period of this research, government initiatives to promote and support breastfeeding possibly contributed to increased breastfeeding in the first hour of life.

The proportion of breastfeeding in the first hour of life in deliveries attended by nurse/obstetrician nurse was significantly higher. A Cochrane systematic review comparing models of care conducted by midwives versus other models of obstetric care has shown that women who received care from a model with midwives were $35 \%$ more likely to breastfeed ${ }^{(20)}$. An issue that may have contributed to the timely initiation of breastfeeding in the presence of nurses concerns the adoption of a care model with reduced use of interventions that could delay the onset of breastfeeding by separating the mother from her child. In a nationwide study published in 2016, the authors highlighted the significantly higher frequency of good practices nurse-attended deliveries ${ }^{(21)}$. In this unique moment for the woman, it is crucial to provide emotional support during delivery, help in identifying the right moment to breastfeed the baby, and intermediation through constant dialogue, so that their wishes are considered. Thus, it may be possible to give the mother the physical and psychological support required to breastfeed in the first hour after giving birth.

Even with the initiatives for the incorporation of obstetrician nurses in delivery and childbirth care in Brazil, considering the importance of this professional to help reduce maternal and perinatal morbimortality ${ }^{(14)}$, of the vaginal deliveries analyzed in this study, only $16.6 \%$ were attended by the nurse/obstetrician nurse, mostly in the public health sector. It is essential to consider that the selected deliveries had sufficient conditions for an uncomplicated physiological follow-up. A study carried out in Minas Gerais pointed out that a model of collaborative delivery care, with a doctor-obstetrician nurse integration in the care team, can reduce the number of unnecessary interventions at childbirth without adversely interfering with neonatal outcomes ${ }^{(22)}$. This model shows its importance when, in the context of maternity, the obstetrician nurse can act in the care of uncomplicated delivery experienced by most women.

Birth in Baby-Friendly Hospitals was significantly associated with breastfeeding soon after birth, an association also found in studies in the South of the country ${ }^{(23)}$ and the city of Rio de Janeiro ${ }^{(24)}$. The accreditation of these hospitals is subject to the adoption of the "Ten Steps", and Step 4 is precisely helping mothers realize when their babies are ready to be breastfed so they can start breastfeeding early ${ }^{(1)}$. At the time of data collection of this research, the criteria for qualification in the IHAC had not yet been redefined with the inclusion of good delivery and childbirth care practices and the assurance of the permanence of the mother or father with the newborn 24 hours a day and free access to both ${ }^{(6)}$.

In a randomized controlled study conducted in Nigeria, the presence of a companion in the delivery room was associated with the shorter time of onset of the first breastfeeding in vaginal deliveries ${ }^{(25)}$. In our study, a significant association was found between the presence of companions at the time of delivery and breastfeeding after birth. A systematic review published in 2014 found no significant association with this outcome, but only one study evaluated this variable ${ }^{(19)}$. The presence of women's free choice companions is regulated by Ordinance $N^{\circ} 2.418 / 2005^{(26)}$ and considered an essential element in the humanization of obstetric care. It may be that women receive emotional support from the companion, giving greater security in the immediate postpartum, favoring the initiation of breastfeeding.

Interestingly, newborns were more likely to breastfeed in the first hour of life in this study. This association was also found in a study conducted in Uganda ${ }^{(27)}$, Ethiopia ${ }^{(28)}$ and a recent study with Hispanic mothers ${ }^{(29)}$, revealing that the gender of the newborn can affect how these mothers see the nutritional needs of their children, possibly related to cultural aspects.

Of the characteristics of prenatal care, only receiving guidance on breastfeeding was associated with the outcome, also identified as a factor associated with early breastfeeding in a study conducted in Bahia $^{(30)}$ and another study in southern Ethiopia ${ }^{(31)}$. This association may be an indication that mothers who had already been advised about the importance of breastfeeding their child soon after birth became more available to this act, or asked for more help from health professionals who attended them in order to implement it. A study carried out in a maternity hospital in the city of Rio de Janeiro revealed that less than half of the puerperae knew about the possibility of breastfeeding in the delivery room ${ }^{(32)}$.

The North region recorded the highest proportion of breastfeeding in the first hour of life, also verified in national studies conducted in 2006 and $2008^{(8,33)}$, which may be related to the cultural issues of the inhabitants of the region ${ }^{(34)}$, percentage of the country's indigenous population ${ }^{(34)}$ and where traditional midwives still work in places that are difficult to access ${ }^{(35)}$.

In terms of maternal sociodemographic characteristics, the groups did not show significant variations, probably due to the relationship between economic class and delivery type ${ }^{(36)}$. In a study carried out in a maternity hospital in Rio de Janeiro, multiparous women were more likely to breastfeed in the first hour ${ }^{(32)}$, as in this study. It may be that multiparous women gave birth to their offspring in a short time and underwent actions favorable to early breastfeeding at first birth, which reflected positively on the second birth. Regarding maternal age, the association was also found in a study carried out in Pelotas, Rio Grande do Sul(23). One possible explanation is that adolescents suffer more educational actions in the health services, since there is concern about adolescent health and identification of their needs in the context of public health, as social subjects in transition from childhood to adulthood ${ }^{(37)}$.

\section{Limitations of the study}

One limitation of this study is that the role of the obstetrician nurse in the delivery and childbirth care process is still being 
strengthened in Brazil and, for this reason, we chose to include nurses without lato sensu training in obstetrics. Also, we could not differentiate the deliveries attended by trained professionals according to ICM standardized competencies. Another limitation concerns the cross-sectional epidemiological design, which hinders a clear causal time-related relationship between exposure and outcome.

\section{Contributions to the nursing, health or public policy area}

We know that the strengthening of the obstetrician nurse's presence involves the adoption of a policy of humanized birth in Brazil that can reverse the logic of obstetric and neonatal care. Continuous professional improvement, aimed at providing quality services, can overcome the obstacles to breastfeeding in the first hour of life within the delivery room. The results of this study may contribute to the strengthening of the IHAC and the Stork Network, and point to the relevance of the development of future research and the reflection on the value of evidence-based care practices, with emphasis on the importance of the role of the obstetrician nurse.

\section{CONCLUSIONS}

We verified that delivery attended by the nurse/obstetrician nurse was associated with a $64 \%$ likelihood of breastfeeding in the first hour of life, even after adjusting for confounding factors.
The association found in this study may be a reflection of the incentive to the professional formation and incorporation of the obstetrician nurse in delivery and childbirth care in Brazil. This study reveals an essential result regarding the promotion of breastfeeding in the first hour of life and may contribute to the strengthening of the obstetrician nurse's work field in the hospital attendance to normal low-risk delivery, in collaborative action with the other professionals. The incorporation of obstetrician nurses into childbirth care does not correspond to the technocratic biomedical model, requiring a review of the care model.

\section{FUNDING}

National Council for Scientific and Technological Development (CNPq); Department of Science and Technology, Secretariat of Science, Technology and Strategic Supplies, Ministry of Health; Sergio Arouca National School of Public Health, Oswaldo Cruz Foundation (INOVA Project); and the Foundation for Research Support of the State of Rio de Janeiro (FAPERJ).

\section{ACKNOWLEDGMENT}

We are grateful to the regional and state coordinators, supervisors, interviewers, and study technical staff, as well as the participating mothers who facilitated this study.

\section{REFERENCES}

1. Ministério da Saúde (BR). Fundo das Nações Unidas para a Infância (Unicef). Iniciativa Hospital Amigo da Criança: revista, atualizada e ampliada para o cuidado integrado: módulo 1: histórico e implementação. Brasília: Ministério da Saúde; 2008 [cited 2018 Feb 27]. (A. Normas e Manuais Técnicos). Available from: http://www.redeblh.fiocruz.br/media/modulo1_ihac_alta.pdf

2. Boccolini CS, Carvalho ML, Oliveira MIC, Pérez-Escamilla R. Breastfeeding during the first hour of life and neonatal mortality. J Pediatr. 2013;89(2):131-6. doi: 10.1016/j.jped.2013.03.005

3. Khan J, Vesel L, Bahl R, Martines JC. Timing of breastfeeding initiation and exclusivity of breastfeeding during the first month of life: effects on neonatal mortality and morbidity--a systematic review and meta-analysis. Matern Child Health J. 2015;19(3):468-79. doi: 10.1007/ s10995-014-1526-8

4. Boccolini CS, Carvalho ML, Oliveira MIC, Vasconcellos AGG. Factors associated with breastfeeding in the first hour of life: systematic review. Rev Saúde Pública. 2011;45(1):69-78. doi: 10.1590/S0034-8910.2014048005278

5. Lansky S, Friche AAL, Silva AAM, Campos D, Bittencourt SDA, Carvalho ML, et al. Birth in Brazil survey: neonatal mortality, pregnancy and childbirth quality of care. Cad Saúde Pública. 2014;30(Sup 1):S1-S15. doi: 10.1590/0102-311X00133213

6. Ministério da Saúde (BR). Portaria GM/MS no 1.153, de 22 de maio de 2014. Redefine os critérios de habilitação da Iniciativa Hospital Amigo da Criança (IHAC), como estratégia de promoção, proteção e apoio ao aleitamento materno e à saúde integral da criança e da mulher, no âmbito do Sistema Único de Saúde (SUS). Diário Oficial da União 2014 May 28. Brasília: Ministério da Saúde; 2014 [cited 2018 Feb 27]. Available from: http://bvsms.saude.gov.br/bvs/saudelegis/gm/2014/prt1153_22_05_2014.html

7. World Health Organization (WHO). Care in normal birth: a practical guide. Maternal and newborn health/safe motherhood unit. Geneva: WHO; 1996.

8. Ministério da Saúde (BR). Centro Brasileiro de Análise e Planejamento (CEBRAP). Pesquisa nacional de demografia e saúde da criança e da mulher - PNDS 2006: dimensões do processo reprodutivo e da saúde da criança. Brasília: Ministério da Saúde, CEBRAP; 2009 [cited 2018 Feb 27]. (Série G. Estatística e informação em saúde). Available from: http://bvsms.saude.gov.br/bvs/publicacoes/pnds_crianca_mulher.pdf

9. World Health Organization (WHO). WHO nursing and midwifery progress report, 2008-2012 [Internet]. Geneva: WHO; 2013 [cited 2017 Nov 04]. Available from: http://www.who.int/hrh/nursing_midwifery/NursingMidwiferyProgressReport.pdf

10. Costa AANM, Schirmer J. A atuação dos enfermeiros egressos do curso de especialização em obstetrícia no nordeste do Brasil: da proposta à operacionalização. Esc Anna Nery Ver Enferm. 2012;16(2):332-9. doi: 10.1590/S1414-81452012000200018

11. Ministério da Saúde (BR). Portaria GM/MS no 1.459, de 24 de junho de 2011. Institui, no âmbito do Sistema Único de Saúde (SUS), a Rede 
Cegonha. Diário Oficial da União, 2011 June 25. Brasília: Ministério da Saúde; 2011 [cited 2017 Nov 04]. Available from: http://bvsms.saude. gov.br/bvs/saudelegis/gm/2011/prt1459_24_06_2011.html

12. Renfrew MJ, McFadden A, Bastos MH, Campbell J, Channon AA, Cheung NF, et al. Midwifery and quality care: findings from a new evidenceinformed framework for maternal and newborn care. Lancet. 2014;384(9948):1129-45. doi: 10.1016/S0140-6736(14)60789-3

13. Lerberghe WV, Matthews Z, Achadi E, Ancona C, Campbell J, Channon A, et al. Country experience with strengthening of health systems and deployment of midwives in countries with high maternal mortality. Lancet. 2014;384(9949):1215-25. doi: 10.1016/S0140-6736(14)60919-3

14. Organização Panamericana da Saúde (OPAS). Centro Latino-Americano de Perinatologia (CLAP), Saúde da Mulher e Reprodutiva (SMR). Conjunto de ferramentas para o fortalecimento da parteira nas Américas [Internet]. Montevidéu: CLAP/SMR; 2014 [cited 2017 Nov 04]. Available from: http://iris.paho.org/xmlui/handle/123456789/49383

15. Ministério da Saúde (BR). Portaria no 353, de 14 de fevereiro de 2017. Aprova Diretrizes Nacionais de Assistência ao Parto Normal. Diário Oficial da União, 2017 Feb 20. Brasília: Ministério da Saúde; 2017 [cited 2017 Nov 04]. Available from: http://www.in.gov.br/materia/-/ asset_publisher/Kujrw0TZC2Mb/content/id/20805342/do1-2017-02-20-portaria-n-353-de-14-de-fevereiro-de-2017-20805260

16. Ministério da Saúde (BR). Diretrizes nacionais de assistência ao parto normal: versão resumida. Brasília: Ministério da Saúde; 2017 [cited 2017 Nov 04]. Available from: http://bvsms.saude.gov.br/bvs/publicacoes/diretrizes_nacionais_assistencia_parto_normal.pdf

17. Vasconcellos MTL, Silva PLN, Pereira APE, Schilithz AOC, Souza Júnior PRB, Szwarcwald CL, et al. Sampling design for the Birth in Brazil: National Survey into Labor and Birth. Cad Saúde Pública. 2014;30:S49-S58. doi: 10.1590/0102-311X00176013

18. Conselho Federal de Enfermagem (Cofen). Resolução Cofen no 479/2015. Estabelece critérios para registro de títulos de Enfermeiro Obstetra e Obstetriz no âmbito do Sistema Cofen/Conselhos Regionais de Enfermagem, e dá outras providências [Internet]. 2015 Apr 14. Brasília: Cofen; 2018 [cited 2017 Nov 04]. Available from: http://www.cofen.gov.br/resolucao-cofen-no-04792015_30971.html

19. Esteves TMB, Daumas RP, Oliveira MIC, Andrade CAF, Leite IC, et al. Factors associated to breastfeeding in the first hour of life: systematic review. Rev Saúde Pública. 2014;48(4):697-708. doi: 10.1590/\$0034-8910.2014048005278

20. Sandall J, Soltani H, Gates S, Shennan A, Devane D. Midwife-led continuity models versus other models of care for childbearing women. Cochrane Database Syst Rev. 2016;4:CD004667 doi: 10.1002/14651858.CD004667.pub5

21. Gama SGN, Viellas EF, Torres JA, Bastos MH, Brüggemann OM, Theme Filha MM, et al. Labor and birth care by nurse with midwifery skills in Brazil. Reprod Health. 2016;13(Suppl 3):123. doi: 10.1186/s12978-016-0236-7

22. Vogt SE, Silva KS, Dias MAB. Comparison of childbirth care models in public hospitals, Brazil. Rev Saúde Pública. 2014;48(2):304-13. doi: $10.1590 /$ S0034-8910.2014048004633

23. Silveira RB, Albernaz E, Zuccheto LM. Fatores associados ao início da amamentação em uma cidade do sul do Brasil. Rev Bras Saúde Materno Infant. 2008;8(1):35-43. doi: 10.1590/\$1519-38292008000100005

24. Esteves TMB, Daumas RP, Oliveira MIC, Andrade CAF, Leite IC. Fatores associados ao início tardio da amamentação em hospitais do Sistema Único de Saúde no Município do Rio de Janeiro, Brasil, 2009. Cad Saúde Pública. 2015;31:2390-400. doi: 10.1590/0102-311X00123114

25. Morhason-Bello IO, Adedokun BO, Ojengbede OA. Social support during childbirth as a catalyst for early breastfeeding initiation for firsttime Nigerian mothers. Int Breastfeed J. 2009;4:16. doi: 10.1186/1746-4358-4-16

26. Ministério da Saúde (BR). Portaria no 2.418, de 02 de dezembro de 2005. Regulamenta, em conformidade com o art. 10 da Lei no 11.108, de 7 de abril de 2005, a presença de acompanhante para mulheres em trabalho de parto, parto e pós-parto imediato nos hospitais públicos e conveniados com o Sistema Único de Saúde - SUS [Internet]. Diário Oficial da União, 2005 Dec 06. Brasília: Ministério da Saúde; 2005 [cited 2017 Nov 04]. Available from: http://bvsms.saude.gov.br/bvs/saudelegis/gm/2005/prt2418_02_12_2005.html

27. Bbaale E. Determinants of early initiation, exclusiveness, and duration of breastfeeding in uganda. J Health Popul Nutr. 2014;32(2):249-60.

28. Lakew Y, Tabar L, Haile D. Socio-medical determinants of timely breastfeeding initiation in Ethiopia: Evidence from the 2011 nation wide Demographic and Health Survey. Int Breastfeed J. 2015;10:24. doi: 10.1186/s13006-015-0050-9

29. Shafer EF, Hawkins SS. The impact of sex of child on breastfeeding in the United States. Matern Child Health J. 2017;21(11):2114-21. doi: $10.1007 / \mathrm{s} 10995-017-2326-8$

30. Vieira TO, Vieira GO, Giugliani ERJ, Mendes CMC, Martins CC, Silva LR. Determinants of breastfeeding initiation within the first hour of life in a Brazilian population: cross-sectional study. BMC Public Health. 2010;10:760. doi: 10.1186/1471-2458-10-760

31. Adugna DT. Women's perception and risk factors for delayed initiation of breastfeeding in Arba Minch Zuria, Southern Ethiopia. Int Breastfeed J. 2014;9:8. doi: 10.1186/1746-4358-9-8

32. Pereira CRVR, Fonseca VM, Oliveira MIC, Souza IEO, Mello RR, Pereira CRVR, et al. Assessment of factors that interfere on breastfeeding within the first hour of life. Rev Bras Epidemiol. 2013;16(2):525-34. doi: 10.1590/S1415-790X2013000200026

33. Ministério da Saúde (BR). Il Pesquisa de Prevalência de Aleitamento Materno nas Capitais Brasileiras e Distrito Federal. Brasília: Ministério da Saúde; 2009 [cited 2017 Nov 04]. Available from: http://bvsms.saude.gov.br/bvs/publicacoes/pesquisa_prevalencia_aleitamento_materno.pdf

34. Instituto Brasileiro de Geografia e Estatística (IBGE). Características gerais dos indígenas [Internet]. In.: Censo Demográfico 2010. Rio de Janeiro: IBGE; 2010 [cited 2017 Nov 04]. Available from: https://censo2010.ibge.gov.br/terrasindigenas/

35. Nascimento KC, Santos EKA, Erdmann AL, Júnior HJN, Carvalho JN. A arte de partejar: experiência de cuidado das parteiras tradicionais de Envira/AM. Esc Anna Nery Rev Enferm. 2009;13(2):319-27. doi: 10.1590/S1414-81452009000200012 
36. Barros AJD, Santos IS, Matijasevich A, Domingues MR, Silveira M, Barros FC, Victora CG. Patterns of deliveries in a Brazilian birth cohort: almost universal cesarean sections for the better-off. Rev Saúde Pública. 2011;45(4):635-43. doi: 10.1590/\$0034-89102011005000039

37. Lopez SB, Moreira MCN. Políticas Nacionais de Atenção Integral à Saúde de Adolescentes e Jovens e à Saúde do Homem: interlocuções políticas e masculinidade. Ciênc Saúde Colet. 2013;18(3):743-52. doi: 10.1590/S1413-81232013000300020 